\title{
Some psychoanalytical meanings of the skin in the book of Job
}

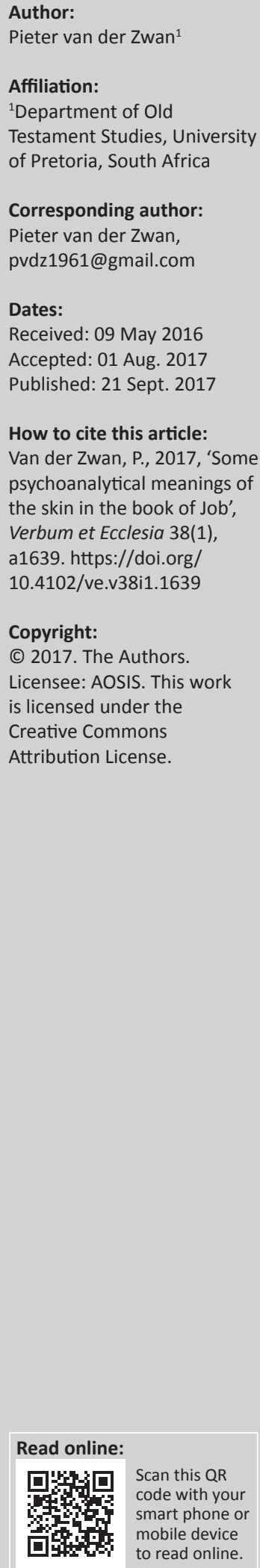

Traditionally, there has been a tension between psychology and religion because of the Freudian critique of religion. This research intends to show that a deeper understanding of religion leading hopefully to an even deeper religiosity can be achieved by studying bodily features portrayed in a (religious) text from a psychoanalytic perspective. Just as any literary character can be 'psychoanalysed' to produce new perspectives on it and on the narrative as a whole, the personality of Job invites the postmodern reader to continue understanding this book on new levels. From this approach, it becomes clear that the protagonist struggles with boundaries and individuation because of his depressive tendencies experienced in issues with reality's harsh touch, nakedness and distance.

Intradisciplinary and/or interdisciplinary implications: Just as any literary character can be 'psychoanalysed' to produce new perspectives on it and on the narrative as a whole, the personality of Job invites the postmodern reader to continue understanding this book on new levels. From this approach, it becomes clear that the protagonist struggles with boundaries and individuation because of his depressive tendencies experienced in issues with reality's harsh touch, nakedness and distance.

\section{Introduction}

The interest in this study derives from the fact that the skin has gained increasing attention in western culture during the last 300 years to develop into a rigid boundary as central metaphor for separation (Benthien 1999:7). This was different from the importance it had before the 18th century when medical doctors had to use its visual and tactile features as expressions of the hidden inside the body. Since the mid-1960s, touch also started to gain interest in the western mind (Montagu 1974:204). All of this could be explained by the postmodern preoccupation with the immanent and the surface where depth and any centrism are denied.

Although there have been some studies on the body of Job (e.g. Basson 2008; Erickson 2013; Jones 2013; Viviers 2002), none of these has applied psychoanalytic perspectives nor has anyone focused on his skin, except Spero (2007:224-227) who regards it as an oral phenomenon because of its enveloping function.

This study will first clarify the underlying hermeneutics in respect of the psychoanalytic approach to the body of the protagonist. Thereafter, the textual evidence about Job's skin illness will be outlined and consequently interpreted in terms of mainly Riemann's psychoanalytic views about the skin to understand Job's problems with reality's harsh touch, nakedness and distance as imposed boundaries to stimulate his individuation. Job is regarded solely synchronically and therefore as a narrative character with no attempt to link him to any historical figure or to the book's author who would have (at least unconsciously) projected his own autobiography onto this character as inevitably happens in all literature.

\section{Hermeneutics}

Interdisciplinary work such as a psychoanalytic approach to Biblical studies is not necessarily supported by the respective disciplines and is often left at their margins, something one could associate with the fragile position of Job at the outskirts and frontiers of his society because of his 'boundary' struggles.

Interpreting the body from a psychological perspective is, however, not new. Berlejung (2012:372) refers to pathognomy, where emotions, life style, actions, social standing, et cetera, are reflected on the body when she compares it to physiognomy where the body reveals character, a diagnosis made by experts in the ancient Near East. 
Psychoanalytic approaches to literature are heterogeneous, and therefore only that of Riemann against his contextual background is applied here.

Early psychoanalysts regarded a literary text as a dream with a latent hidden meaning behind a manifest content. This meaning could be reached by identifying and decoding mechanisms such as displacement expressed in language as metaphors, which Charles Mauron (1964) focused on in his psychocriticism of literature and which plays an important role in the book of $J o b$.

The original psychoanalytic claim that body images and their meanings remain constant has been critiqued by deconstructionism's growing insight into their historical relativity. As Claudia Benthien (2002:36) puts it: 'The skin marks not only an actual but also a profoundly symbolic boundary that is subject to cultural and historical change'. The skin is constantly being renegotiated.

Yet language has always retained the affinity between a sense of identity and the skin, as is proven by numerous idioms, proverbs (cf. Job 2:4, 19:20) and metaphors. In the same way, just as the brain and the skin always develop from the same membrane, the ectoderm, so these two body parts remain closely related (Benthien 1999:14).

Despite postmodernism's unmasking of any claim to universality as a myth, the unconscious, just like anatomical functions, still appears to be part of the human condition. Certain psychoanalytic insights are therefore assumed to be applicable to all cultures and times and valid for the interpretation not only of historical but also of fictional characters. One of these insights is that the body expresses various (changeable) meanings also in texts, as Reilich (2013:300) phrased it: 'Der Körper als sprachbildliches Kondensat des alttestamentlichen Menschen ist literarischer Schauplatz des physischen, sozialen und religiös-spirituellen Zerfalls'.

Although other critics have applied psychoanalytic approaches to the author(s) of a biblical text, the characters in a narrative and the reception of a text, it is here limited to the main protagonist and focused on his body and more specifically on his skin to reveal his inner experiences.

\section{The condition of Job's skin}

The book of Job excels with references to the body, when not literally (including animal bodies), then figuratively, almost in every verse. Above all, it is about a body under attack, especially imaged as military.

Job's health problems are in the first place a skin illness, though there are indications of perhaps other physical suffering as indicated in 6:10.12, 9:17, 9:28, 16:6.8, 17:7, 19:27, 30:17a, 33:21 and 34:6, for instance, if some of them are not metaphors of psychological and spiritual suffering. Habel (1985:95-96) does not regard it as any identifiable illness, but unnatural, from Satan, poetic, not medical, thus opening it up as a metaphor with psychoanalytic meanings. Heckl (2010:348) regards it as a generalised description of צִּ [wrongly translated as 'leprosy'] in Leviticus 13 and 14 as it is mentioned only in the prologue and not quite in agreement with other skin problems mentioned in 7:5b, 19:26 and 30:30.

Mary Douglas (1999:212) likewise notes the connections between the books of Leviticus and Job, which both use Priestly language and themes. It is not necessary to link this skin illness to death (cf. Nm 12:12) as Heckl (e.g. 2010:264n192) repeatedly does. In 2:12 מֵרחוֹק [from afar] seems to be in agreement with the separation prescribed in Leviticus 13, but או [with him] in the very next verse creates a problem in that it seems to contradict this distance. The ground or earth (לָאָָרץץ (in 2:13 might be different and a distance away from the

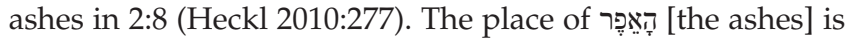
perhaps not the same as that in 1:20 but a place outside the city as the Septuagint also interprets it and in this way links it with Leviticus13:46 and Numbers 12:14 (Heckl 2010:266).

The word עוֹ [skin] occurs 10 times in the book of Job, that is, more than $10 \%$ of the 99 times which it occurs in the Hebrew Bible. In addition, the hapax legomenon, גִלִדי [my skin], probably Aramaic, in 16:15 brings the total times that the skin is mentioned explicitly to 11 . Ten of these instances are about Job and only 10:11 (giving the positive counterpart of Ezk 37:8) and 40:31 celebrate the miracle of the skin. In the former, it is about his own and in the latter about the skin of the leviathan. This last-mentioned instance is the only time in the Hebrew Bible where it does not refer to a dead animal which has been skinned. Sometimes the word for skin is not mentioned explicitly, but referred to, as in 2:7.8.12 and in

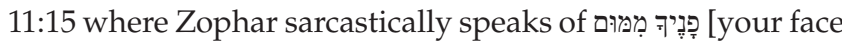
without spot]. Various interlocutors mention the skin amongst whom Satan (who actually challenged God to touch Job's bone and flesh in 2:5) is first while God has the last word about the 'ideal' skin of the leviathan. Bildad mentions it in 18:13 and the remaining mentions all come from Job, the one who is probably most aware of it because of his plight in that very part of his body.

In 2:4 the folk saying or proverb probably refers metonymically to the whole body as it perhaps also does in 18:13. The first mention in 2:4 could refer to one body part of Job which he might be willing to sacrifice in order to save another, to his life, to the skin of his children or of his animals while the second to his own skin. Heckl (2010:261) mentions that this verse is sometimes understood as stemming from a context of trade but interprets it as a parallelism in which the first mention refers to clothing as last possession (Job 1 is about his private property, such as his children) and the second to human life, dealt with in Job 2. The fact that means 'around' (as in 1:10) could imply that Job is 'undressed'; he is 'peeled' layer for layer: first his possessions, then his children (both as extensions of his body), now his clothes, skin, flesh and bones. There is no need to follow Clines (1989:43-44) who believes it to refer to the lex talionis of Exodus 21:23-25. 
The word שִ שִחין [boil] in 2:7 also occurs in Exodus 9:9.10.11(twice) as one of the plagues against the Egyptians, in Leviticus 13:18.19.20.23 where, in a context about צִ צִ is one of seven skin illnesses ranging from clean to unclean the priest can deal with, in Deuteronomy 28:27.35 in a list of God's threatened punishments ending up in exile and in 2 Kings 20:7 which is verbatim as in Isaiah 38:21 and about king Hezekiah's boil. Job's boil is thus associated with both the exodus and the exile, two situations of being an outsider.

This is one of the only two places (the other being Deut 28:35) in the Hebrew Bible where it is qualified by רָע [sore]. It derives from the verb שחן [to be hot, probably also to 'be inflamed' as in Arabic], an experience hinted at by 30:30 where blackness adds this same sense but now suggests being burnt from the outside. Alternatively, its heat could stem from the hunger inside him, as in Lamentation 5:10, or could be associated to his anger, but these possibilities are open and depend on the exact context.

In all these cases, the heat is negatively connoted, perhaps a reason for his having to get rid of his covering (vide infra). Apart from that, his boils seem to have caused an itch, as suggested by $2: 8$.

They totally cover him, but it is a false cover as the eruptions on his skin make him 'leak' in 7:5 where o from מָָָ [dissolve, melt]. This could refer to his suppurating sores or to sweating because of fever. If Job fears emptying himself out, he would see his skin as a non-containing sieve through which he loses vital fluids, where no protection is offered and which threatens to depersonalise him (Anzieu 1995:124).

The sense of emptiness seems to have a prominent place in the book of $J o b$ and is expressed by various interlocutors. In 7:3 (Job speaks), 11:11 (Zophar speaks), 15:31 (twice, Eliphaz speaks), 30:3.14, 31:5 (paralleled to מִרְְָ [deceit], Job speaks), 35:13 (Elihu speaks) and 38:27 (God speaks), various forms of שָָׁ [emptiness, nothingness, vanity] occur. In 11:12 Zophar insinuates that Job is an נִבוּב [empty] man. Other expressions show that this sense occurs mostly with Job (7 times), twice with Elihu and twice with God, but none of these ever with any of the three friends: כִי-איון [for nought] in 35:15 (Elihu speaks); הֶֶ [vanity] in 7:16 (Job speaks); 9:29 (Job speaks), 21:34 (Job speaks), 27:12 (Job speaks), 35:16 (Elihu speaks) and לָּרָּב [in vain] in 39:16 (God speaks derivatives (be in vain, a liar, an illusion) in 6:28 (Job speaks), 34:6 (Job

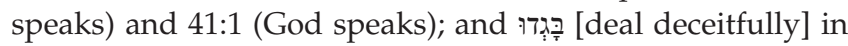
6:15 (Job speaks).

Before one interprets this word in an abstract way as meaninglessness, worthlessness or illusion, the concrete would always have preceded it in the mind, and so physical and bodily emptiness was the initial experience. Variations of

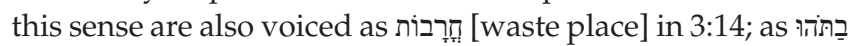
[into the waste] in 6:18; as [vanity] in 7:16, 9:29 and 21:34;

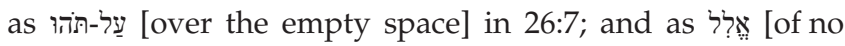

value] in 13:4, for instance. Job speaks in all these cases. Suffering as coincidental waste is denied by Eliphaz in 5:6.

Similar to a sense of leaking (and unconsciously subsequent

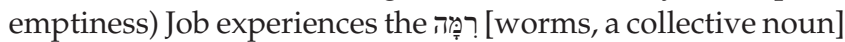
under his skin in 7:5 as breaking his unity. This symbol of death is psychologically well explained by Connor (2004):

the impulse to the neurotic excoriation, and the desire to cleanse oneself of sebaceous material and other visible deposits in the skin ... mutates, in the obsessives and psychotics described by Freud and Bion, into a horrified, but lingering libidinous identification with the worms that occupy the pores of the skin. (The long, thin extrusions of sebaceous matter were mistaken for dead worms by some earlier observers.) (p. 244)

Its sense of multiplicity suggests the fragmentation which Job is experiencing in his skin (Connor 2004:247) and

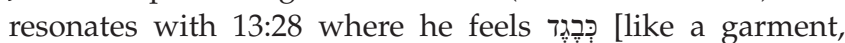

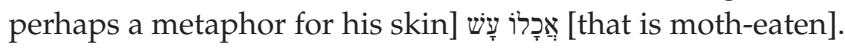
The question can be asked whether Job feels invaded by worms (the schizoid's paranoia) or if he believes them to be crawling from his own inner self (the depressive's low selfesteem as in 16:15 [vide infra]). Alternatively, when meant literally, these vermicular animals could take advantage of the excretions from his skin and through their subtle movement create a sensation of touch, with all its associations of punishment in the book of Job. If that is, in fact, the case, then Heckl's (2010:349; 62n134) diagnosis of it as a 'parasitäre Erkrankung' (parasitical illness), and not the 'leprosy' of Leviticus 13:2ff., as the period of illness is too long, might be correct. Job's skin - standing for his whole body - is being eaten as 18:13 also confirms.

Yet the horror of 'leaking' suggests a pressure from inside the body. Elihu perhaps and unintentionally mirrors something of Job's own explosive struggle when he experiences his

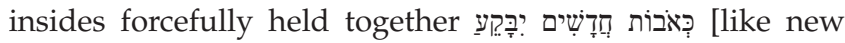
wineskin ready to burst] in 32:19.

In 7:5, עָפָּר [dust] represents the outer reality of the earth which is now sticking onto Job's skin because of his suppurating sores and penetrating to his very flesh because his skin as barrier has been broken, or worse, been 'flayed'. It also reminds of לָאָָָ [for small dust] in Exodus 9:9, which is likewise connected to, or at least associated with, skin illness.

Perhaps because of emaciation and being 'eaten' by death and its representatives, the worms, Job might experience losing his sense of unity and might fear falling apart and so is desperately clinging to his skin in 19:20: it is his bones and not his skin which keep him together. His bones do not cleave to his flesh as in Psalm 102:6 but hold his skin together to compensate for its failing containing function, to become a

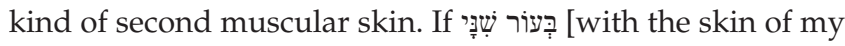
teeth] does not refer to his gums as so many have speculated but is meant literally, that is, he is left with nothing, as his teeth have no skin (Alter 2010:83), it adumbrates the next verse where the skin is mentioned, viz. 19:26, and now for the first time as non-existing. 
Dhorme (1963:18) believes that this last-mentioned verse hints at the מָָָ [curtain, covering, screen] of the tabernacle in Exodus 39:34, for instance, relating it indirectly to the Akkadean word for skin, 'mašku'. This would imply that behind this skin or 'curtain', the divine mystery will be visible.

Having his skin destroyed, perhaps by literal fire, it now falls from Job in 30:30, if this is not an expression of a fear of losing his skin. Alternatively, inflammation and fever might be implied and therefore Heckl (2010:349) regards it as different from leprosy as described in Leviticus 13:2ff. Habel (1985:159) correctly recognises more a corps than a living body in these images.

The impenetrable armour of the leviathan in 40:31 symbolises the strong and thick skin which is idealised by the thinskinned Job. In 41:5 it cannot be undressed and in 41:7 its outer protection of pride has closed it off from the world. The psychoanalyst, Frances Tustin (1972:126) on whom Anzieu (1995:57.267) builds, actually mentions a crustacean ego, which is like an animal compensating for the lack of the containing and protective functions with rigid armour-shell. Here the monster's skin is filled and reinforced with attacking weapons in anticipation of aggression as in the narcissistic attitude with its second skin. Yet in 41:8, the monster's scales has a kind of intimate closeness to each other, the very sense of inner integration that Job is lacking and longing for. Its scales are therefore firmly in place and not falling apart as in any scale disease.

The epilogue does not mention Job's skin illness and might therefore even imply that it has not been healed as Deuteronomy 28:27 mentions perhaps the same boils which Job also suffers from as the first of a list of incurable skin illnesses. This might be meant by Job himself as well in 34:6

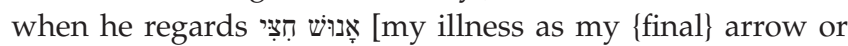
wound]. Yet because he is blessed with a family again it could mean that he must have been healed and reintegrated from his isolation back into society. Heckl (2010:357) leaves the option open that 42:10 could refer to a waiting period like that in Leviticus 13:21. In Job there is, however, no priest who declares him impure and later pure again. To all these doubts, 40:10 seems to come as the surprise where he is decked with beauty and all kinds of grace (vide infra).

\section{Psychoanalytic views on the skin}

By 'exposing' Job psychologically, one rids him of his idealised heroism and shows him as merely human, with the important theological implication that God is put in the centre instead.

Within the German-speaking context, the neo-psychoanalyst Fritz Riemann (1902-1979) has identified four personality types: schizoid, depressive, compulsive and hysterical, which defend against four different anxieties: about proximity, distance, change and necessity, respectively. The first two anxieties are polar opposites on the same continuum, whereas the last two likewise belong together. Opposites tend to attract but also frustrate each other as they promise complementarity. What is lacking in each can, however, only be fully reached vicariously through the partner. These four types represent the psychoanalytic developmental cutaneous (not recognised by Freud), oral, anal and genital stages and are different approaches to certain existential 'boundaries'. It is therefore not surprising that the word 'Grenze' (boundaries) has a high frequency in Riemann's work.

The individualist schizoid could not develop basic trust because of their experience that the 'common skin' (which everyone shares with the mother in the womb and for a period thereafter also psychically) has been ripped off prematurely (Anzieu 1995:63-64). This leads to a premature 'own skin' and constant suspicions about others because of fear of losing the self. As the personality remains unstable, fragile and hypersensitive, continuous experiences of their true selves being hurt emotionally by others make the person to withdraw and to build a kind of carapace of distance and independence. They therefore rely strongly on causal connections and the practical value of piety. As they do not sense belonging, however, they do not value tradition. Although they crave closeness and intimacy, they also fear it. It is as if their skin is too thin and permeable, as if they are too 'open'. The benefit is that more is invested in individuation to the extent that these people often appear as outsiders and odd, something an exceptional character such as Job could experience. This problem to understand them invites society to project unresolved and unintegrated issues onto them and they can easily and ironically become scapegoats despite their efforts to keep a low profile. Those who cannot be classified are then considered as 'impure' or even transgressors. Boundaries are not experienced as bridges but used as barriers which they assert to the extent that their aggression is often regarded as narcissistic sadism. Problems with the sensory organs as orifices, the skin and breathing are their typical bodily expressions of their struggle to connect with the outside world (Riemann 2006:53). Their loneliness can make them experience life as empty, which they compensate for by a rich imagination. Authenticity is so important to them that their honesty somehow renders them 'naked', which they then have to cover with a 'second skin' (Bick 1988:189).

One reason for depressive personalities is that they have remained too long in the maternal 'common skin' and when it is removed, they are unprepared and experience it as flaying and their 'own skin' remains too 'thin' so that the 'touch' of reality is felt as harsh. Too much permeability allows too much to infiltrate, resulting in too many negative images to be introjected. Nevertheless, they fear separation, loss and loneliness and so become dependent and even addicted to the partner whom they try to make dependent, sometimes by inducing guilt feelings, on them as well in order to secure closeness. As they also lack a thick enough 'skin', they empathically and 'selflessly' sacrifice and surrender themselves (often as masochists) in the other who is admired but also envied for the courage to individuate, 
which they fear themselves, making them feel guilty and depressed. Their projective identification comes about through constant introjection of the often 'poisonous' beloved with whom they try to mystically merge with no boundary or skin separating them (Riemann 2006:86). It is as if they want to regress to the womb sharing a common skin with the mother. Having a strong sense of belonging to their group as well, they tend to constantly adjust and lack enough aggression to assert their own identity as they avoid conflict. This camouflage and adaptation is then rendered into a protective ideology of piety and faithfulness. This can exhaust them as they always need to repress their true self.

Fearing change and transience, the obsessive-compulsive personality seeks security in constancy, control and striving for perfection, and so fixes the identity of tradition, of themselves and of the partner with power and rules. Others are hardly regarded as equal, but either dominated or regarded as norm. Their exaggerated sense of economy and endurance makes them cling to their possessions and principles at the cost of spontaneous human relationships.

Fearing finality, the hysterical person cherishes freedom and avoids obligations. They creatively but naively seduce others with fantasy worlds by denying reality-based restrictions and disregarding tradition. They tend to play roles rather than risk authenticity. They believe in miracles and grace and undermine the connection between deeds and consequences, which is somehow what the book of Job also does.

In this study, personality types will be substituted by changeable tendencies and positions used for the fictional character of Job as he develops psychologically. Only the schizoid and depressive tendencies are considered here because of their close link with the skin and because of Job's characteristics. It would seem that Job develops from depressive tendencies, through his encounter with God, imaged by his culture as anally compulsive, to a new stance with more independence and individuation on the schizoid side, when he has dealt with his too 'thin skin'. Changing the skin symbolises changing identity, and then often through an initiation illness as amongst shamans.

\section{Touch in the book of Job}

Some of the Hebrew words for illness suggest an attack on the body, that is, on the skin in the first place. In the book of Job, one finds forms of 1: 1:11.19, 2:5, 4:5, 5:19, 6:7 and 19:21, all with negative connotations, which occurs 61 times in Leviticus 13-14 about צַָָָּ ['leprosy'], as it always does in the Priestly and Deuteronomistic sources. In the Hebrew Bible, God is always the subject, although it could originally refer to demonic attacks (Milgrom 1991:776).

Depressive 'moaning' tendencies also occur in Job. In 6:4 he feels infiltrated by God's venom and in 6:9 he accuses God of sadism (and therefore as the distant schizoid). In general, Job tries to make God guilty for not being limited by the connection between human deeds and consequences and in this way staying transcendent, separate, different and independent from Job who, however, remains dependent on God. Yet something masochistic in him seems to exult in pain in 6:10.

Not only does Job feel the harsh 'touch' of God but also misses the loving touch of his children, all who have tragically died. Skin contact and other sensual experiences are often interpreted as guarantee for reliable bonding: the meaning of good-enough boundary experiences allows the self to form boundaries (Paar 2002:60). As these painful separations are still hard to tolerate, the skin substitutes their absences with illness as some kind of stimulus. Job's exclusion and resultant loneliness is because of a lack of contact, both physical and socio-emotional, which would have confirmed his relational identity in terms of belonging to the collective. To express this loss symbolically and therefore 'touch' the collective, Job shaves his hair and tears his clothes in 1:20.

Despite the terrible touch of 'God' (actually Satan, but not so understood by Job), Job's feeling out of touch with God is somehow expressed by Job's sense of nakedness.

\section{Clothing and nakedness in the book of Job}

Clothing can serve as external marker of identification, as in Hosea 2:11 and Zephaniah 1:8. It is this identity which is dramatically changing for Job.

Tearing his mantle and shaving his head in 1:20 as physical demonstrations of his words in the very next verse about his ultimate nakedness, Job is subsequently 'covered' by boils in 2:4 and his broken skin 'clothed' in 7:5 by worms and dust, both symbols of death, just as nakedness is in 26:6. Nakedness can sometimes mark those who somehow survive without God, as in 24:7.10 and 27:16-17, while being clothed suggests God's caring presence (cf. Ezk 16:8f.). Being naked is like having no boundaries, as both these ideas are almost juxtaposed in 22:5-6. Not only do his people distance themselves from Job, but so do even his clothes in a

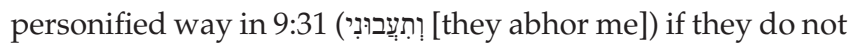
burn him because of the hot south wind in 37:17.

This is such a contrast to his original state of being protected and held together by God through the skin in 10:11 where the clothing metaphor is strengthened by the reference to textile

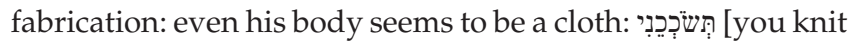
me together].

In 19:9, Job claims that God הִפְשׁיט [has stripped] him of his honour. In all cases in the book of Job where גָּ and its derivatives mean 'to uncover' or 'to open', God is (at least by implication) the subject: in 12:22 (deep places), 20:27 (the heavens reveal iniquity), 33:16 (ears), 36:10.15 (ears) 38:17 (the gates of death) and 41:5 (face of Leviathan's garment).

To compensate for his skin's failing functions of containment, identity-pride and protection, Job sews שֵׁ [sackcloth] to put 
onto his skin as a symbol of mourning and humiliation, as his 'horn' (i.e. pride, perhaps even referring to his very skin) lying in the dust in 16:15 also suggests. This reminds of what the first couple and then God did in Genesis 3:7.21, respectively, to hide humanity's shame, perhaps because of the bodily difference between the two sexes. It is precisely Job's bodily difference (with its moral implications in his culture) that also gets him expelled from his home, just as were the original transgressors.

In the process of disintegration undressing (starting with the gradual 'denuding' of Job's existence in chapter 1 and 2:4 [vide supra]) even leads to disembodiment or excarnation in 19:26 where נִקְּפו [they have struck off, stripped] him of his skin, a state which may even be idealised: this progressive undressing will eventually open his eyes to God.

It is as if flesh and skin (as clothing or mask) made him blind. The threat of blindness is also mentioned immediately after skin illnesses in Deuteronomy 28:27-28, perhaps to play with

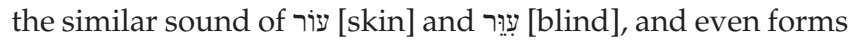
of ערה [naked], all three of which would have been associated in the unconscious. This link suggests that the skin is also the site of shame (cf. 8:22), not a mask hiding the real self, but the surface exposing the essence of the self that needs to be hidden by 'second skins'. Benthien (1999:116) claims that in the Indo-Germanic languages, 'shame' and 'skin' likewise share the same root word and Roland Barthes saw loving as being 'skinless', both these instances suggesting a possible universal link between the two concepts.

The eyes of others will also be opened as Job's piety has been suspected as being only skin-deep, as merely pragmatic camouflage. His true colours will now be shown to Satan and to the world, to all who have been blind as well until now. Job is seen as impersonating the preferred role and so as exchanging his true self for the imposed clothing he was made to wear through collective projection. In that sense, he has been crossing the borders of his authentic self to mirror, duplicate and clone the collective ideal made physically present but now doubted in the (collective) crisis. In this sense, Job's denuding is a transformation process for all.

Job is stripped of any persona just as when counsellors and priests in 12:17 שוֹלָל [stripped] when God exposes them. It is not the first time that the skin is used to disguise the truth: skin also serves as cover-up when Jacob conned his blind father by making him think he is actually his brother, Esau, by 'wearing' the same texture and body odour (Gn 27:15-16).

Any defences Job had are to become transparent. His sense of nakedness is so ironic, as he was the very one to clothe the destitute in 31:19, although Eliphaz accuses him of 'disrobing' even the naked in 22:6, clearly an impossibility and therefore a hyperbole to express the extremity of his accusation.

To compensate for the exposure, Job has to form a thick, rigid mummified cover in what would normally be regarded as a claustrophobia-inducing coffin as second skin. This is perhaps reflected in Job's regressive phantasies to the womb as grave in 3:11. Job therefore longs back to the womb in 10:18-19 when the skin which replaced it, disintegrates and does not 'clothe' him anymore (Van der Zwan 2015:175).

When the skin does not contain anymore, it has to be contained in quarantine as 'hospitalisation' outside society (cf., e.g., Foucault 1961 passim), as is the case with Job who is not only expelled from the privacy of his home but also feels terribly naked. Job is also divested of his social 'clothing' when he is isolated.

This longing for containment is expressed by various forms חתם [seal] in 9:7 (the sun), 14:17 (Job's history), 24:16 (here negative, however), 33:16 (God's decree), 37:7 (God limits man's power), 38:14 (perhaps nature) and 41:7 (Leviathan's skin).

Yet, just as God clothes nature in 38:9.14 and 39:19, he clothes Job again in 40:10 with majesty, excellence, glory and beauty, from which he has stripped him in 19:9. From this restitution, one may infer that his skin illness has been healed as well (vide supra).

\section{Proximity and distance}

Job's attitude to proximity is an important factor in interpreting his skin condition. References to distance occur twice as many times in the book of Job as those mentioning proximity: רח [be\{come\} far] or its derivatives can be found in 2:12 (the third-person narrator: Job's friends are far from him); 5:4 (Eliphaz: the fool's children are far from safety); 11:14 (Zophar: Job should distance himself from iniquity); 13:21 (Job prays that God withdraws his hand from him but begs for contact in the next verse); 19:13 (Job bemoans the estrangement of his close ones); 21:16 (Job distances himself from bad advice); 22:18 (Eliphaz feels distanced from bad advice); 23 (Eliphaz tells Job to distance himself from iniquity); 30:10 (Job bemoans being rejected even by outcasts, just like those in Lamentations 4:8); 36:3 (Elihu has extraordinary sources of insight); 25 (Elihu: even farsightedness recognises Gods greatness) and 39:25 (God: the horse can smell a battle from afar); 29 (God: the eagle's hyperopia). These instances show that Job and his friends regard distance as negative while God and Elihu do so with positive connotations.

When people are experienced as distant as in 19:13, the presence of God is also hard to sense in the preceding verses, for instance. God is then perhaps interpreted as transcendent and being beyond all human boundaries and capabilities, as perhaps in 36:3.

Because of the problematic touch of God, proximity can be קֶרָ

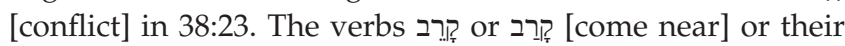
derivatives occur in 31:37 where Job wants to go near to God. But in 33:22, Elihu threatens with death's proximity, in 17:12 
Job regards the darkness close to the light (though the meaning is dubious) and in 19:14, Job's close ones are estranged. From this, one can sense that Job feels isolated and craves for the belonging in the presence of God and lovedones.

Yet this distance imposed on him somehow exists right at the start already. Job is located in 1:1 in the land of Uz, perhaps in the foreign, non-Israelite context of Edom. Heckl (2010:353) claims that the poetic part of Job portrays him and his friends as pagans, whereas the frame leaves his identity open. Even if Job is an Israelite as Wolfers (1995:84) argues, he still lives in an area at the edge of Israelite society and in the shadow of foreign invasion. That the three friends are non-Israelites and distant visitors testifies that Job had friendly relations with his border neighbours.

Despite the absence of any explicit explanation of the name, the protagonist must have appeared as ex- or pre-Israelite, a non-Israelite sage (Heckl 2010:374), to the original recipients (Heckl 2010:228; cf. also Brenner 1989:40,46). There is at least a play on the word לִאיוֹיב [as enemy] in 13:24 in the passive sense and in 33:10 in the active sense, with the name as metaplasm of 'enemy'.

No father, brothers, sisters or in-laws are mentioned. Heckl (2013:87) notes the similarity between 42:10 and Deuteronomy 30:3. Job was as if in exile and individualises this collective experience.

In 19:13-19, his social isolation is described. Not only is he a foreigner to Judah but also in his own home in this foreign

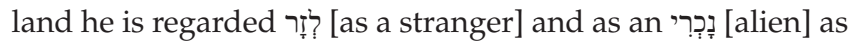
19:15 claims, just like his acquaintances who זָר [are estranged] from him in verse 13. Yet he was the one who took care of the ม [stranger] according to 31:32. Job is now even physically attacked in 6:23, 16:10f. and 17:6b, for instance.

As the site of encounter with the outside world, the skin speaks about his problematic interpersonal relationships. Although Job has a large family with a wife, children on behalf of whom he even empathically sacrifices and numerous servants as well as friends and acquaintances whom he experiences as not making meaningful emotional contact with him (11:3-4, 19:13-19 and 30:9-14, for example), but only as harming him (16:10), the public gloats in 12:4 and 17:6 at his misery and spit at him. In 30:1-10 even those who are themselves repressed outcasts from society and whom he previously supported distance themselves from him. It is quite possible that envy of his piety had penetrated Job's being and now triumphantly celebrates his demise.

\section{Job at the boundaries}

That no word for 'wall' but only a few contested architectural 'orifices' occur in the book of Job makes one wonder whether the author is not all that sensitive to or assertive of boundaries: [gate] or its derivatives occur in 5:4 (associated with trauma), 29:7 (perhaps the only one not negatively nuanced),
31:21 (again linked to violence) and 38:17 (of death and of its shadow), while țֶָ? [door] or its derivatives occur in 3:10 (of the womb, sounding violent), 31:32 (open to the stranger), 38:8 (of the sea) and 41:6 (of Leviathan's face, if they refer to his mouth, then also with associations of violence). In 16:14 and 19:10, however, it sounds as if a city wall has been attacked (Fohrer 1988:288.313 respectively).

Job in 3:17-19 also blurs the boundaries between social castes as well as between those with healthy and those with problematic bodies in Sheol, and in this way critiques the general views of his time. This universalism is typical of the wisdom tradition, but it is experienced as traumatic for anxious conservatives. Boundaries seem to be problematised in the book of Job and Job's trauma is discovering and questioning them existentially and physically in his own life, as 11:7-9, for instance, illustrates: wisdom is beyond all boundaries. Yet it seems from 16:3 and 22:5 that human pretences at wisdom are endless as well. Yet in [limit, amongst other related meanings such as statute] and its derivatives occur 45 times in the book together with in 38:33 (and וירחקו [were inscribed] in 19:23), which seem to suggest a general awareness of limitations (vide supra). In addition, some verbs and their derivatives denoting bondage, bandaging or girding such as אָּ (3:18, 12:18, 36:8.13, 39:5),

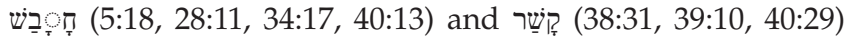
occur across the whole book, but the last verb clusters around the end. Nouns such as [ֶר [noose] in 18:10 (pains/portion/

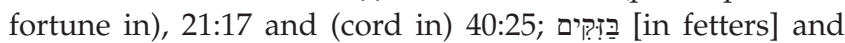

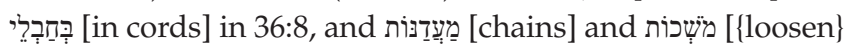
the bands/cords] in 38:31 add to this general atmosphere of bondage. Different from creation God is, however, beyond limits, as in 36:26.

Trauma can, amongst others, be defined as the transgression of one's psychological boundaries. For Job this started with the breaking down of physical boundaries outside of himself: in 1:10 Satan points out to God: שְְַׁ [you hedged] him and his possessions. In 3:23 God likewise protects the one who travels in darkness: וזיֶָָּ [and he covered, hedged \{him\}].

The painful presence of the skin urges transcendence of the boundaries of the body (cf. also Erickson 2013:297). This is already implied by the loss of definition when the skin breaks and leaks as adumbration of his disintegrating body as a whole.

Job's world-view threatens to disintegrate just as his body as their respective boundaries are challenged. He pleads for containing boundaries in 24:1-2 where they are transgressed and celebrates them in 26:10. Both man in 26:14 and 28:3 and God in 28:24 are aware of their existence. His boundaries are in flux and in crisis: in 12:18 God loosens the מלוּס [bond] of kings, only to bind them instead. This forces Job to develop a distanced critical view.

Although Dhorme (1963:17) claims that the skin is hardly ever used metaphorically in Hebrew or Akkadean, the liminality of Job's being (Basson 2008:294) is suggested by the 
skin as his limen, which is repeatedly in focus as disintegrating. It symbolises his transition from one state to another as the skin bridges the inside and the outside as two polarities. It also symbolises the mediation in rites of passage and according to Van Gennep (1960:43) lies between separation and re-aggregation, between being stripped and reintegration or re-assimilation. Turner (1969:95) regards this middle stage as one of anti-structure and chaos where the person is neither here nor there, bordering on madness. Having reached the limit, Job is painfully born into a new existence.

Connor (2004:230) formulates it well by speaking of a 'rising to the surface of ourselves' and 'centring of ourselves at our edges' in a crisis period.

\section{Conclusion}

The skin in the book of Job has multiple layers of meaning, expressing different psychic functions, depending on the context. The protagonist's skin suggests that he is taken to the very edge of his body and the ultimate boundaries of his existence. Through trauma at these extremities Job can recognise that God has no 'skin' and therefore transgresses the rigid boundaries imposed on him by culture's compulsive religiosity. By accepting the distance and difference between God and himself, Job develops psychologically to a greater degree of individuation from his tradition. He is now 'clothed' by his own beauty and gently touched by God's infinite power and grace.

Although being the outsider, Job ironically becomes allinclusive through the book's universal appeal to transcend all 'skin' variations. Boundaries and borders, including the skin, in the book of Job are relative and constantly in flux and in crisis but also creative and transformative.

\section{Acknowledgements}

This article forms part of a post-doctoral programme enabled by the National Research Foundation for which the author is extremely grateful. It was further supported by an Erasmus Mundus scholarship for research at Leipzig University under the supervision of Prof. Dr Raik Heckl from 01 August 2015 until 31 January 2016 for which the author is most thankful as well.

\section{Competing interests}

The author declares that he has no financial or personal relationships that may have inappropriately influenced him in writing this article.

\section{References}

Alter, R., 2010, The wisdom books: Job, proverbs and Ecclesiastes: A translation and commentary, W. W. Norton, New York.

Anzieu, D., 1995, Le moi-peau, Dunod, Paris.

Basson, A., 2008, 'Just skin and bones: The longing for wholeness of the body in the book of Job', Vetus Testamentum 58, 287-299. https://doi.org/10.1163/1568533 08X301980

Benthien, C., 1999, Haut: Literaturgeschichte, Körperbilder, Grenzdiskurse, Rowohlt, Reinbek bei Hamburg.

Benthien, C., 2002, Skin: On the cultural border between skin and the world, Columbia University Press, New York.

Berlejung, A., 2012, 'Menschenbilder und Körperkonzepte in altorientalischen Gesellschaften im 2. und 1. Jt. V. Chr. Ein Betrag zur antiken Körpergeschichte', in A. Berlejung, J. Dietrich \& J.F. Quack (eds.), Menschenbilder und Körperkonzepte in alten Israel, in Ägypten und im alten Orient, pp. 367-397, Orientalische Religionen in der Antike, Mohr Siebeck, Tübingen.

Bick, E., 1988, 'The experience of the skin in early object-relations', in E.B. Spillius (ed.), Melanie Klein today, vol. 1, pp. 187-191, Internationaler Psychoanalyse, Munich.

Brenner, A., 1989, 'Job the Pious? The characterization in the narrative work of the book', Journal for the Study of the Old Testament 43, 37-52. https://doi.org/ $10.1177 / 030908928901304303$

Clines, D.J.A., 1989, Job 1-20, Word, Dallas, TX.

Connor, S., 2004, The book of skin, Reaktion Books, London.

Dhorme, E., 1963, L'emploi métaphorique des noms des parties du corps en hébreu et en akkadien, Librairie orientaliste Paul Geuthner, Paris.

Douglas, M., 1999, Leviticus as literature, Oxford University Press, Oxford.

Erickson, A., 2013, '“Without My Flesh I Will See God”: Job's rhetoric of the body', Journal of Biblical Literature 132(2), 295-313. https://doi.org/10.2307/23488013

Fohrer, G., 1988, Das Buch Hiob, Evangelische Verlagsanstalt, Berlin.

Foucault, M., 1961, Folie et Déraison. Histoire de la folie à l'âge Classique, Librairie Plon, Paris.

Habel, N.C., 1985, The book of Job, SCM, London.

Heckl, R., 2010, Hiob: Vom Gottesfürchtigen zum Repräsentanten Israels, Forschungen zum Alten Testament 70, Herausgegen von Bernd Janowski (Tübingen), Mark S. Smith (New York) \& Hermann Spiekermann (Gőttingen), Mohr Siebeck, Tübingen.

Heckl, R., 2013, 'The relationship between Job 1-2, 42 and 1 Sam 1-4 as intertextual guidance for reading', in K. Dell \& W. Kynes (eds.), Reading Job intertextually, pp. 81-93, Bloomsbury, New York.

Jones, S.C., 2013, 'Corporeal discourse in the book of Job', Journal of Biblical Literature 132(4), 845-863. https://doi.org/10.2307/42912470

Mauron, C., 1964, Des métaphores obsédantes au mythe personnel: Introduction à la psycho-critique, Corti, Paris.

Milgrom, J., 1991, Leviticus, [1], 1-16: A new translation with introduction and commentary, Doubleday, New York.

Montagu, A., 1974, Körperkontakt: Die Bedeutung der Haut für die Entwickung des Menschen, transl. E. Zahn, Ernst Klett, Stuttgart.

Paar, G.H., 2002, 'Selbstverletzung als Selbsterhaltung', in M. Hirsch (ed.), Der eigene Körper als Symbol? Der Körper in der Psychoanalyse von heute, pp. 53-72, Psychosozial, Gießen.

Reilich, M., 2013, Grenzfall Mensch: Biblische Impulse für eine Theologie der Berührung, Stuttgarter Biblische Beiträge 69, Katholische Bibelwerk, Stuttgart.

Riemann, F, 2006, Grundformen der Angst: Eine tiefenpsychologische Studie, Ernst Reinhardt, Munich.

Spero, M.H., 2007, 'Hidden Subject of job: Mirroring and the anguish of interminable desire', in G. Glas (ed.), Hearing visions and seeing voices: Psychological aspects of biblical concepts and personalities, pp. 213-266, Springer, Dordrecht.

Turner, V.W., 1969, The ritual process: Structure and anti-structure, Routledge \& Kegan Paul, Chicago, IL.

Tustin, F., 1972, Autism and childhood psychosis, Hogarth, London.

Van der Zwan, P., 2015, 'Bedeutungen und Bilder der Gebärmutter in der Hebräischen Bibel', Journal for Semitics 24(1), 169-197.

Van Gennep, A., 1960, The rites of passage, Routledge \& Kegan Paul, London.

Viviers, H., 2002, 'Body and nature in Job', Old Testament Essays 14(3), 510-524.

Wolfers, D., 1995, Deep things out of darkness: The book of Job: Essays and a new English translation, Kok Pharos, Kampen. 